\title{
Ethylene involvement in chilling injury symptoms of avocado during cold storage
}

\author{
Edna Pesis ${ }^{a, *}$, Miriam Ackerman a, Rosa Ben-Arie ${ }^{a}$, Oleg Feygenberg a, \\ Xuqiao Feng ${ }^{b}$, Akiva Apelbaum ${ }^{b}$, Raphael Goren ${ }^{b}$, Dov Prusky ${ }^{a}$ \\ a Department of Postharvest Science of Fresh Produce, A.R.O., The Volcani Center, PO Box 6, Bet Dagan 50250, Israel \\ ${ }^{\mathrm{b}}$ Faculty of Agriculture, The Hebrew University of Jerusalem, Rehovot, Israel
}

Received 2 November 2000; accepted 25 May 2001

\begin{abstract}
Application of exogenous ethylene, irrespective of the method of application, caused intensification of mesocarp discoloration in avocado fruit (Persea americana Mill.) during cold storage of all cultivars tested. 'Ettinger' fruit treated with Ethrel (2-chloroethyl phosphonic acid) prior to packing and storage developed severe chilling injury (CI) symptoms, expressed as mesocarp discoloration after 3 weeks at $5{ }^{\circ} \mathrm{C}$. 'Fuerte' fruit treated with ethylene gas $(100 \mu 1$ $1^{-1}$ ) for $24 \mathrm{~h}$ at $20{ }^{\circ} \mathrm{C}$ prior to storage at $5{ }^{\circ} \mathrm{C}$ exhibited mesocarp discoloration, which increased dramatically during shelf life at $20^{\circ} \mathrm{C}$. 'Fuerte' fruit treated in cold storage with a continuous low ethylene dose $\left(4 \mu 11^{-1}\right)$ developed severe browning in the fruit pulp after 3 weeks at $5{ }^{\circ} \mathrm{C}$. 'Hass' fruit treated with $50 \mu 11^{-1}$ ethylene, for 12,24 or 48 $\mathrm{h}$ at $5{ }^{\circ} \mathrm{C}$ showed a gradual increase in mesocarp discoloration after 3 weeks in cold storage plus shelf life; the $48 \mathrm{~h}$ ethylene-treated fruit exhibited the most severe pulp browning. Use of absorbent sachets that removed ethylene from modified atmosphere (MA) packaging reduced mesocarp discoloration and decay development in 'Hass' fruit after 5 weeks storage at $5{ }^{\circ} \mathrm{C}$. Application of 1-methylcyclopropene (1-MCP), reduced mesocarp discoloration, decay development and polyphenol oxidase activity, whereas this enzyme activity was induced in ethylene-treated fruits that were cold stored for 4 weeks. (C) 2002 Elsevier Science B.V. All rights reserved.
\end{abstract}

Keywords: Persea americana; Chilling injury; Ethrel; 1-Methylcyclopropene; Ethylene absorbent; Modified atmosphere

\section{Introduction}

Darkening of the mesocarp during cold storage is one of the chilling injury (CI) symptoms expressed in avocado fruit (Chaplin et al., 1982;

\footnotetext{
* Corresponding author. Tel.: +972-3-968-3612; fax: + 972-3-968-3622.

E-mail address: epesis@agri.gov.il (E. Pesis).
}

Bower et al., 1989; Cutting et al., 1990), and browning of the pulp causes major export losses every year (van Lelyveld and Bower, 1984). Mesocarp discoloration in the form of brown pulp results from oxidation of $o$-diphenols to $o$ quinones, by polyphenol oxidase (PPO), and these continue to oxidize to form brown melanin pigments (Kahn, 1976). Kahn (1977) demonstrated a relationship between degree of pulp darkening 
and PPO activity in various avocado cultivars, and a relationship has also been shown between pulp browning and phenol content (van Lelyveld and Bower, 1984).

Several means to reduce CI symptoms in avocado have been examined including: controlled atmosphere (CA), modified atmosphere (MA), anaerobiosis and heat treatments. Hatton and Reeder (1972) showed that removal of ethylene from avocado cv. Lula stored in CA at $10{ }^{\circ} \mathrm{C}$ increased percent acceptable fruit after storage. Storage in CA $\left(2 \% \mathrm{O}_{2} ; 10 \% \mathrm{CO}_{2}\right)$ at $5.5{ }^{\circ} \mathrm{C}$ for 28 days reduced mesocarp discoloration of 'Fuerte' fruit (Bower et al., 1989). Application of anaerobiosis for $24 \mathrm{~h}$ prior to storage at $2{ }^{\circ} \mathrm{C}$, reduced ethylene production and CI symptoms in 'Fuerte' fruit (Pesis et al., 1994). Acetaldehyde, the first metabolite in anaerobic respiration, inhibited ethylene formation, ACC oxidase activity and pulp browning in avocado (Pesis et al., 1998). Heat treatment prior to cold storage reduced external CI symptoms and extended ripening time, and was associated with lower ethylene production (Woolf et al., 1995). Heat treatments were also the most effective in reducing CI symptoms in 'Fuerte' and 'Hass' fruit, when applied on the day of picking (Kremer-Kohne, 1999). Storage in MA with high $\mathrm{CO}_{2}$ and reduced ethylene levels resulted in reduced CI symptoms in avocado (Scott and Chaplin, 1978; Meir et al., 1997).

The relationship between ethylene and CI in avocado is still not clear. Treatment with ethylene enhances ripening during shelf life without injury (Zauberman et al., 1988), and recently, it was shown that application of 1-methylcyclopropene (1-MCP) to avocado fruit at $22{ }^{\circ} \mathrm{C}$ inhibited ripening at $22{ }^{\circ} \mathrm{C}$; this was expressed as delayed fruit softening and ethylene production (Feng et al., 2000).

In the present study, we have observed the effects of ethylene on development of internal CI symptoms during prolonged cold storage. In addition, we studied the efficacy of application of 1-MCP during cold storage, or removal of ethylene by absorbents, in reducing CI symptoms during cold storage.

\section{Material and methods}

\subsection{Fruit and ethylene treatments}

Avocado fruit (cv. Ettinger) were dipped in Ethrel (2-chloroethyl phosphonic acid) solution $\left(500 \mu \mathrm{g} \mathrm{ml}^{-1}\right.$ ) prior to packing and storage (DeWilde, 1971). Ethrel-treated and non-treated fruits were stored at 4,6 or $8{ }^{\circ} \mathrm{C}$ for 3 weeks. In addition, Ethrel-treated and non-treated fruits were stored at $20{ }^{\circ} \mathrm{C}$ to examine ripening without cold storage. Following cold storage, firmness was determined and the fruits removed to shelf life at $20{ }^{\circ} \mathrm{C}$ and held until the fruit had softened, after which mesocarp discoloration was examined.

'Fuerte' fruit were treated with ethylene gas $\left(100 \mu 1^{-1}, 24 \mathrm{~h}\right.$ at $20{ }^{\circ} \mathrm{C}$ ), while control fruit were held for $24 \mathrm{~h}$ at $20{ }^{\circ} \mathrm{C}$ in an ethylene-free room. All fruit were transferred to $5{ }^{\circ} \mathrm{C}$ for 3 weeks and then removed to $20{ }^{\circ} \mathrm{C}$ until they softened. In another experiment, 'Fuerte' fruit were treated continuously with ethylene gas $(4 \mu \mathrm{l}$ $1^{-1}$ ) for 3 weeks at $5{ }^{\circ} \mathrm{C}$.

'Hass' fruit were treated with ethylene gas (50 $\mu 11^{-1}$ at $5^{\circ} \mathrm{C}$ ) for 12,24 or $48 \mathrm{~h}$ and then stored at 3 or $5{ }^{\circ} \mathrm{C}$ for $2-3$ weeks, while control fruit were placed immediately at 3 or $5{ }^{\circ} \mathrm{C}$. Firmness was checked upon removal to $20{ }^{\circ} \mathrm{C}$ (fruit temperature had equilibrated to $20^{\circ} \mathrm{C}$ ) after 2 and 3 weeks in cold storage, and mesocarp discoloration was assessed after fruit had softened.

\subsection{Modified atmosphere packaging}

'Hass' fruit were packed in microperforated polyethylene (PE) bags. Four kilograms of fruit were sealed in PE $\left(50 \times 60 \mathrm{~cm}^{2}, 40 \mu \mathrm{m}\right)$ film, which was microperforated with 30 needle holes, to achieve MA condition. Half of the bags contained two ethylene absorbent sachets (Ethysorb, Stayfresh Ltd., UK), comprising potassium permanganate on activated alumina (6 g per sachet). During 5 weeks of cold storage, concentrations of $\mathrm{CO}_{2}, \mathrm{O}_{2}$ and ethylene in the MA bags were monitored once a week by sampling the gases via a silicon septum with a $10 \mathrm{ml}$ syringe, and subjecting the sample to gas chromatography (GC; Pesis et al., 1994). 


\subsection{1-Methylcyclopropene application}

In all experiments, 1-MCP was applied to fruit on the day of picking, at the start of the cold storage. Avocado fruit (around $20 \mathrm{~kg}$ ) cvs. Fuerte and Hass, were placed in sealed $30-1$ plastic tanks at 3 or $5{ }^{\circ} \mathrm{C}$, and treated with $1-\mathrm{MCP}$, at various concentrations $\left(100-300 \mathrm{nl} \mathrm{1}^{-1}\right)$ and for various durations $(24-48 \mathrm{~h})$. Control fruit were also sealed in tanks, but not treated with 1-MCP. The levels of $\mathrm{CO}_{2}, \mathrm{O}_{2}$, and ethylene were monitored during the treatment in the sealed tanks. In some experiments, fruits received a second application of 1-MCP (100 or $\left.300 \mathrm{nl} \mathrm{l}^{-1}\right)$ for 24 or $48 \mathrm{~h}$ while in cold storage. The plastic tanks containing the fruits were ventilated for $30 \mathrm{~min}$ at $20{ }^{\circ} \mathrm{C}$ before the fruit were packed into cartons and placed again in cold storage. 1-MCP gas was applied by injecting a measured volume of stock gas preparation into the sealed containers. The 1-MCP was synthesized according to Sisler and Serek (1997). Fruits were stored for a total of 1 month at 3 or $5{ }^{\circ} \mathrm{C}$ and then removed to $20^{\circ} \mathrm{C}$ for 5 days.

\subsection{Polyphenol oxidase activity}

PPO activity was determined on mesocarp tissue that had been frozen in liquid $\mathrm{N}_{2}$ and kept at $-80{ }^{\circ} \mathrm{C}$ until activity measurements were made. A 5-g sample of mesocarp was homogenized in 20 $\mathrm{ml}$ of $0.1 \mathrm{M}$ phosphate buffer, $\mathrm{pH} 6$, together with $1 \mathrm{~g}$ of polyvinylpolypyrrolidone (PVP). PPO activity was expressed in units based on the change in optical density at $410 \mathrm{~nm}$ during $2 \mathrm{~min}$ of incubation with 4-methyl catechol as a substrate (Kahn, 1977). Protein concentration was determined with the Bio-Rad reagent (Bradford, 1976). Results are expressed as units per mg protein.

\subsection{Fruit ripening and chilling injury indices}

Fruit firmness was determined by destructive and non-destructive methods. In the destructive method, firmness was measured on two cheeks of each fruit, using an electronic penetrometer (Chatillon, New York) with a 6.5-mm conical tip.
In the non-destructive measurements, firmness was graded by hand touch, according to a descending 10 point scale: firm fruit 10 , elastic fruit 5 , soft fruit 1 . The firmness index was calculated by the following formula:

Firmness index

$=\frac{\sum_{10}^{1}(\text { Index level })(\text { Number of fruit in this level })}{\text { Total number of fruit }}$.

CI of peel was exhibited as blackening and pitting of the exocarp. The peel injury index was calculated on an ascending 10 point scale: 0 no injury, 1 low injury: $10 \%$ of the fruit injured, 5 medium damage: $30 \%$ of the fruit injured, 10 high injury level: $50 \%$ or more of the peel injured. The CI index was calculated according to the following formula:

$$
\begin{aligned}
& \text { CI index } \\
& =\frac{\sum_{0}^{10}(\text { Index level })(\text { Number of fruit at this level) }}{\text { Total number of fruit }} .
\end{aligned}
$$

CI of the pulp, expressed as mesocarp discoloration, was assessed on completely soft fruit (ready to eat) after removal to $20{ }^{\circ} \mathrm{C}$. The fruit was cut longitudinally into two halves for examination of pulp appearance. Internal damage expressed as mesocarp discoloration was calculated as the percentage of the total number of fruit with internal browning.

Percent decayed fruit was also calculated, according to the number of fruit with stem-end rot or side rot.

The experiments were repeated over two consecutive years. Fruit were sampled from commercial packinghouses on the day of packing (1 day after harvest). For the 1-MCP experiments, fruit were taken on the day of harvesting prior to packing.

\subsection{Statistical analysis}

Each treatment was applied to five export cartons. A 4-kg carton contained 14-16 fruit of cvs. Ettinger and Fuerte or 16-18 fruit of cv. Hass. Most data were expressed as mean $\pm \mathrm{SE}$. The results of gas analysis in MAP are means of five 

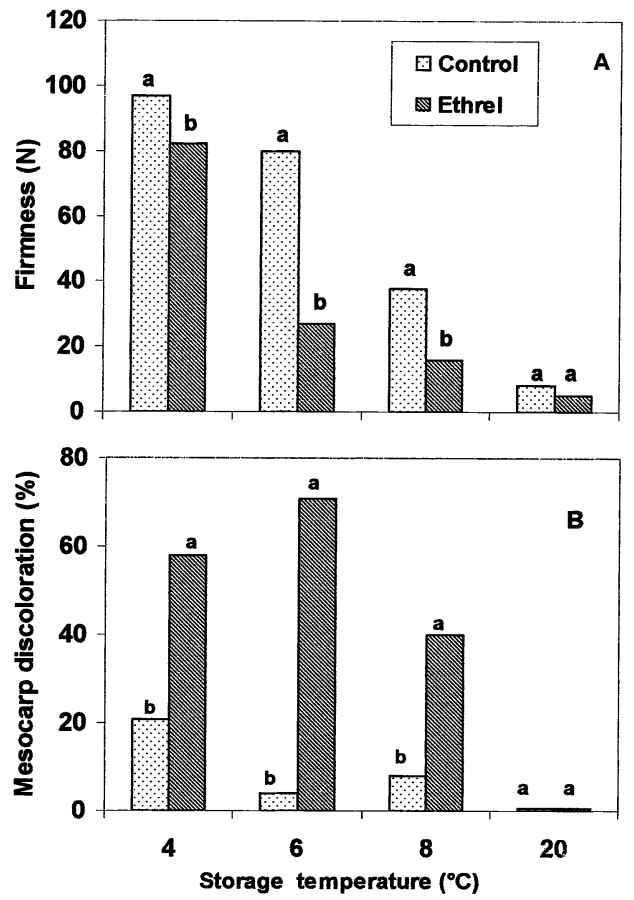

Fig. 1. Effect of an Ethrel dip before storage on fruit firmness $(N)$ and mesocarp discoloration of 'Ettinger' fruit following 3 weeks storage at 4,6 or $8{ }^{\circ} \mathrm{C}$, or storage immediately at $20{ }^{\circ} \mathrm{C}$ (A). Mesocarp discoloration ( $\%$ of fruit) was determined after the fruit softened completely after removal to shelf life at $20{ }^{\circ} \mathrm{C}$ (B). Mean separation in each storage temperature by Duncan's multiple range test, $5 \%$ level.

samples. The least significant difference (LSD) at $5 \%$ was calculated for each gas. Some of the data were analyzed with the Statistical Analysis System (SAS, 1998). Means were separated by Duncan's multiple range test at $P<0.05$. Arcsin $\sqrt{ } P$ transformation was performed prior to the analysis for all results that are expressed as percentages.

\section{Results}

\subsection{Effect of applied exogenous ethylene}

Dipping 'Ettinger' fruit in Ethrel solution (500 $\mu 11^{-1}$ ) prior to packing and cold storage accelerated softening upon removal from storage at 4, 6 or $8{ }^{\circ} \mathrm{C}$ after 3 weeks (Fig. 1(A)). After 3 weeks of storage, the non-treated controls and the Ethrel-treated fruits from the highest temperature $\left(8{ }^{\circ} \mathrm{C}\right)$ softened much more quickly than those from 4 to $6{ }^{\circ} \mathrm{C}$. The Ethrel-treated fruit developed severe mesocarp discoloration (up to $70 \%$ of the fruits), when they were ripened at $20{ }^{\circ} \mathrm{C}$ following 3 weeks storage at all temperatures tested (Fig. 1(B)). The highest mesocarp discoloration was found in the Ethrel-treated fruit that had been stored at 4 or $6{ }^{\circ} \mathrm{C}$. On the other hand, in the Ethrel-treated fruit stored at $20{ }^{\circ} \mathrm{C}$ for 8 days no mesocarp discoloration was observed, and fruit softened similarly to control fruit (Fig. 1). The untreated 'Ettinger' fruit showed more mesocarp discoloration at $4{ }^{\circ} \mathrm{C}(20 \%)$ than at higher temperatures (6 and $8{ }^{\circ} \mathrm{C}$; Fig. 1$)$.

Storage of 'Fuerte' fruit at $5{ }^{\circ} \mathrm{C}$ after application of ethylene gas $\left(100 \mu 1^{-1}, 24 \mathrm{~h}\right.$ at $\left.20^{\circ} \mathrm{C}\right)$ caused severe CI symptoms exhibited as exocarp injury and mesocarp discoloration (Table 1). Mesocarp discoloration in ethylene-treated fruit increased to $61.5 \%$ compared with zero browning in the control fruit. However, firmness did not differ between the ethylene-treated and the control fruits after 6 days of shelf life (Table 1).

Storage of 'Hass' fruit at 3 or $5{ }^{\circ} \mathrm{C}$ after application of ethylene gas $\left(50 \mu 11^{-1}, 12-48 \mathrm{~h}\right.$ at $5{ }^{\circ} \mathrm{C}$ ) caused severe $\mathrm{CI}$ symptoms, expressed as mesocarp discoloration (Fig. 2). After short stor-

Table 1

Effect of ethylene application $\left(100 \mu 11^{-1}, 24 \mathrm{~h}\right.$ at $20^{\circ} \mathrm{C}$ ) on fruit firmness (index 10-1), CI exocarp (index 0-10) and CI mesocarp discoloration (\% of fruit) of 'Fuerte' fruit after 2 and 6 days at $20{ }^{\circ} \mathrm{C}$ following 3 weeks at $5{ }^{\circ} \mathrm{C}$

\begin{tabular}{lllllll}
\hline Treatment & After 2 days at $20{ }^{\circ} \mathrm{C}$ & & \multicolumn{2}{c}{ After 6 days at $20{ }^{\circ} \mathrm{C}$} & \\
\cline { 2 - 3 } & Firmness (index) & CI exocarp (index) & & Firmness (index) & CI exocarp (index) & CI mesocarp (\%) \\
\hline Control & $8.60 \mathrm{a}$ & $0.14 \mathrm{~b}$ & & $4.10 \mathrm{a}$ & $0.71 \mathrm{~b}$ & $0.0 \mathrm{~b}$ \\
$\mathrm{C}_{2} \mathrm{H}_{4}$ & $6.87 \mathrm{~b}$ & $2.57 \mathrm{a}$ & $5.56 \mathrm{a}$ & $4.27 \mathrm{a}$ & $61.5 \mathrm{a}$ \\
\hline
\end{tabular}

Mean separation in columns by Duncan's multiple range test, $5 \%$ level. 

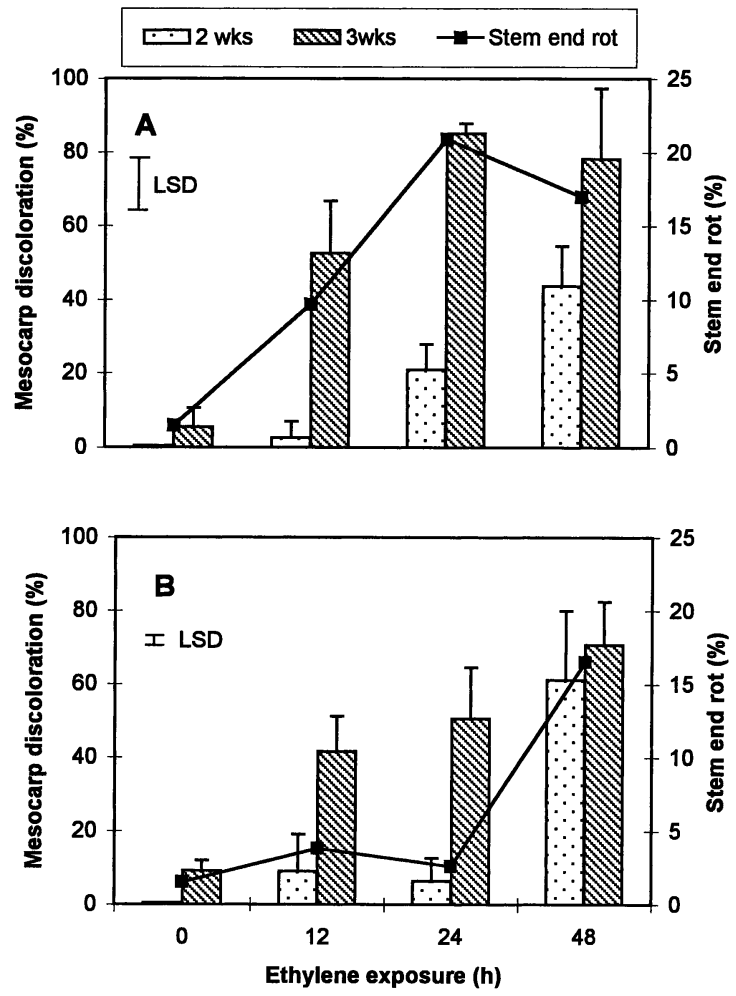

Fig. 2. Effect of application of ethylene on 'Hass' fruit $(50 \mu 1$ $1^{-1}$ at $5{ }^{\circ} \mathrm{C}$ ) for different durations $(12,24$ or $48 \mathrm{~h})$ on mesocarp discoloration ( $\%$ of fruit) and stem-end rot development ( $\%$ of fruit). Indices were determined after 6 days at $20{ }^{\circ} \mathrm{C}$ in soft fruit, following cold storage for 2 or 3 weeks at (A) $3{ }^{\circ} \mathrm{C}$ or (B) $5{ }^{\circ} \mathrm{C}$. Data are mean \pm SE. LSD at $5 \%$ level for $\%$ rot at $3{ }^{\circ} \mathrm{C}=2.82$; at $5{ }^{\circ} \mathrm{C}=1.03$.

age at 3 or $5{ }^{\circ} \mathrm{C}$ for 2 weeks and removal to shelf life for softening, there was slight mesocarp discoloration in the 12 and $24 \mathrm{~h}$ ethylene-treated fruit. However, during the same storage time, $50-60 \%$ of the 48 -h ethylene-treated fruit, developed mesocarp discoloration (Fig. 2). After 3 weeks of storage at 3 or $5{ }^{\circ} \mathrm{C}$, the percentage of fruit exhibiting mesocarp discoloration increased dramatically in the 12- and 24-h ethylene-treated fruit (Fig. 2). At both temperatures, ethylenetreated fruit developed much more stem-end rot than control fruit (Fig. 2). After 3 weeks, the percentage of fruit suffering from mesocarp discoloration and stem-end rot development was slightly higher in the fruit stored at $3{ }^{\circ} \mathrm{C}$ than in those at $5{ }^{\circ} \mathrm{C}$ (Fig. 2(A) vs. (B)). The 24 and $48 \mathrm{~h}$ ethylene treatments, but not the 12-h treatment, caused slight fruit softening $(95-114 \mathrm{~N})$ compared with control fruits $(130-137 \mathrm{~N})$ upon removal from cold storage after 3 weeks.

\subsection{Effect of ethylene absorbent}

Addition of ethylene absorbent sachets to MA packaging of 'Hass' fruit reduced concentrations of ethylene and $\mathrm{CO}_{2}$ and increased $\mathrm{O}_{2}$ in $\mathrm{PE}$ bags (Fig. 3). After 5 weeks at $5{ }^{\circ} \mathrm{C}$, ethylene concentrations were almost zero in MA packaging with ethylene absorbent sachets, whereas ethylene con-

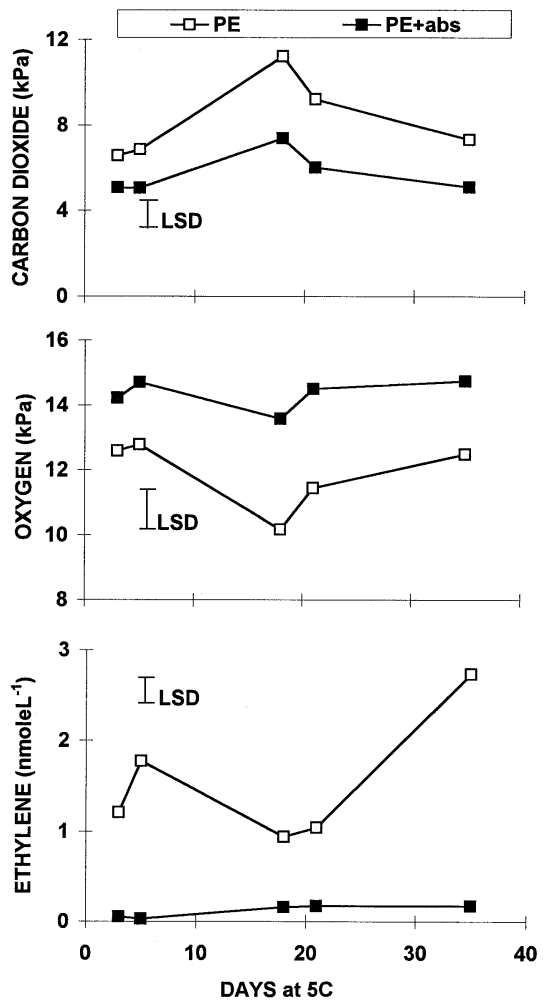

Fig. 3. Effect of MA in microperforated PE bags with ethylene absorbent sachets (PE + abs.) and without sachets (PE) on accumulation of $\mathrm{CO}_{2}, \mathrm{O}_{2}$ and ethylene in 'Hass' fruit during 5 weeks of storage at $5{ }^{\circ} \mathrm{C}$. Data are means of five measurements. LSD at $5 \%$ level for $\mathrm{CO}_{2}=1.16 ; \mathrm{O}_{2}=1.31 ; \mathrm{C}_{2} \mathrm{H}_{4}$ $=0.36$. 
Table 2

Effect of two ethylene absorbent sachets (MA+abs.) in MA packaging on decay development (\%) and mesocarp discoloration (\%) in 'Hass' fruit after 3 and 7 days at $20{ }^{\circ} \mathrm{C}$ following 5 weeks at $5{ }^{\circ} \mathrm{C}$

\begin{tabular}{lllll}
\hline Treatment & $\begin{array}{l}\text { Shelf life at } 20{ }^{\circ} \mathrm{C} \\
\text { (days) }\end{array}$ & \multicolumn{2}{l}{ Decay development $(\%)$} & $\begin{array}{l}\text { Mesocarp discoloration } \\
(\%)\end{array}$ \\
\cline { 3 - 5 } & & Side rot & Stem-end rot & $34.8 \mathrm{a}$ \\
MA & 3 & 0.0 & $28.0 \mathrm{a}$ & $18.1 \mathrm{~b}$ \\
MA+abs. & 3 & 0.0 & $0.0 \mathrm{c}$ & $32.9 \mathrm{a}$ \\
Air control & 3 & 0.0 & $2.9 \mathrm{~b}$ & $71.2 \mathrm{a}$ \\
MA & 7 & $11.7 \mathrm{a}$ & $77.4 \mathrm{a}$ & $21.5 \mathrm{~b}$ \\
MA+abs. & 7 & $8.6 \mathrm{a}$ & $14.5 \mathrm{c}$ & $88.5 \mathrm{a}$ \\
Air control & 7 & $2.7 \mathrm{~b}$ & $49.5 \mathrm{~b}$ & \\
\hline
\end{tabular}

Mean separation in columns in the various dates by Duncan's multiple range test, $5 \%$ level.

centrations in the MA packaging without sachets reached around $3 \mathrm{nmol}^{-1}$ (Fig. 3).

Storage of 'Hass' fruit (without any fungicide treatment) in MA for 5 weeks led to decay development, especially stem-end rot, compared with unwrapped fruit (Table 2). In MA packaging with ethylene absorbent sachets, fruit exhibited significantly less mesocarp discoloration and lower stem-end rot levels. The levels of the side rots were relatively low and did not differ between fruit stored in MA and those in MA plus absorbent sachets (Table 2).

\subsection{Effect of applied 1-methylcyclopropene}

During the application of 1-MCP to 'Hass' fruit at $5{ }^{\circ} \mathrm{C}$ in sealed containers, there was accumulation of $\mathrm{CO}_{2}$ to about $6 \mathrm{kPa}$ and the concentration of $\mathrm{O}_{2}$ dropped to $13 \mathrm{kPa}$ after $24 \mathrm{~h}$ in both treated and untreated fruits (Table 3). In the second enclosure of the fruits with 1-MCP for $24 \mathrm{~h}$ at $5{ }^{\circ} \mathrm{C}$, the increase in $\mathrm{CO}_{2}$ was much lower and the $\mathrm{O}_{2}$ concentrations remained around $15 \mathrm{kPa}$ (Table $3)$. Ethylene levels were very low on the first day of application. However, in the second enclosure after 10 days at $5{ }^{\circ} \mathrm{C}$, there was accumulation of 1.09 and $0.84 \mu 1^{-1}$ of ethylene after $24 \mathrm{~h}$, with 1 -MCP applications of 100 and $300 \mathrm{nl}^{-1}$, respectively (Table 3).

Application of 1-MCP to 'Hass' fruit (100 nl $1^{-1}$ for $24 \mathrm{~h}$ at $5{ }^{\circ} \mathrm{C}$ ) was not enough to reduce mesocarp discoloration completely. However, a second application $\left(100 \mathrm{nl}^{-1}\right)$ caused further reduction in mesocarp discoloration, without interfering with the softening process after 5 weeks at $5{ }^{\circ} \mathrm{C}$ (Table 3). Application of 1-MCP (300 nl $1^{-1}$ for $24 \mathrm{~h}$ at $5^{\circ} \mathrm{C}$ ) reduced mesocarp discoloration significantly and did not prevent softening. However, a second application of 1-MCP $\left(300 \mathrm{nl}^{-1}\right)$ after 10 days impaired the softening of 'Hass' fruit: the fruit failed to soften normally and remained firm during shelf life (Table 3).

'Fuerte' fruit suffered from a significant amount $(50 \%)$ of mesocarp discoloration after 6 days at

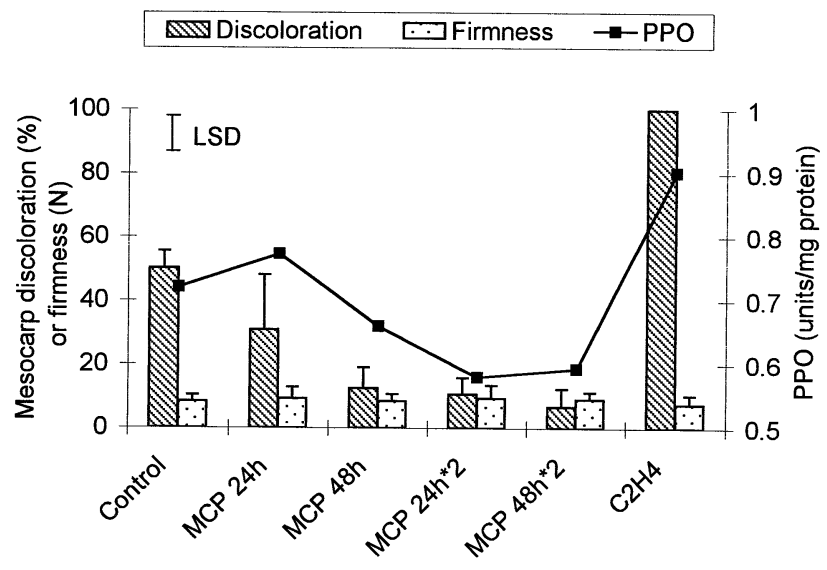

Fig. 4. Effect of 1-MCP (100 $\left.\mathrm{nl} \mathrm{l}^{-1}\right)$ applied for 24 or $48 \mathrm{~h}$ starting on the first day of cold storage and a second time after 2 weeks at $5{ }^{\circ} \mathrm{C}(24 \times 2$ and $48 \times 2)$, on 'Fuerte' fruit quality. Fruit firmness $(N)$ and mesocarp discoloration (\% of fruit) and PPO activity were measured after 6 days of shelf life at $20{ }^{\circ} \mathrm{C}$ following 4 weeks at $5{ }^{\circ} \mathrm{C}$. Data are mean \pm SE. LSD at $5 \%$ level for $\mathrm{PPO}=0.45$. 


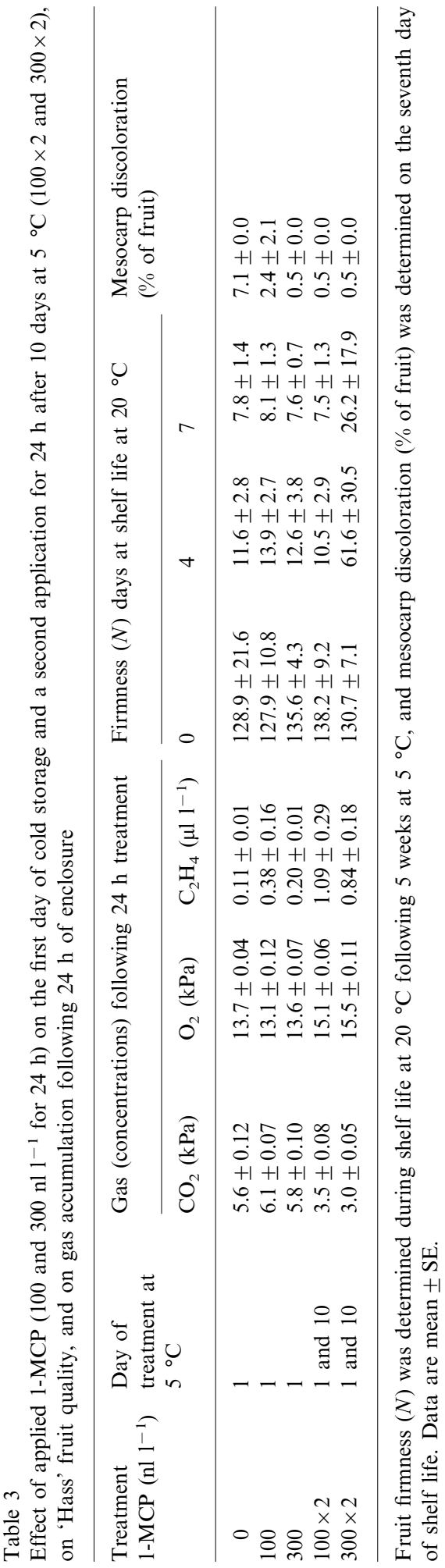



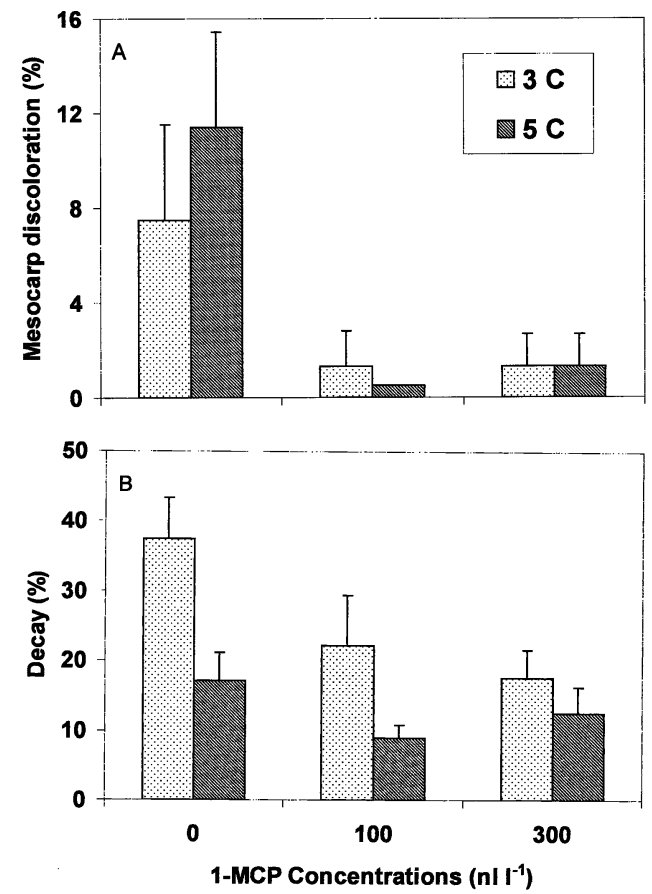

Fig. 5. Effect of 1-MCP (100 or $\left.300 \mathrm{nl} \mathrm{1}^{-1}\right)$ applied for $24 \mathrm{~h}$ on the first day of cold storage on 'Hass' fruit quality. Mesocarp discoloration ( $\%$ of fruit) and decay development ( $\%$ of fruit) were measured after 6 days of shelf life at $20{ }^{\circ} \mathrm{C}$ following 5 weeks at 3 or $5{ }^{\circ} \mathrm{C}$. Data are mean $\pm \mathrm{SE}$.

$20{ }^{\circ} \mathrm{C}$ following 4 weeks at $5{ }^{\circ} \mathrm{C}$ (Fig. 4). Application of 1-MCP $\left(100 \mathrm{nl} \mathrm{1}^{-1}\right)$ for 24 or $48 \mathrm{~h}$ at $5{ }^{\circ} \mathrm{C}$ to 'Fuerte' fruit caused a gradual reduction in mesocarp discoloration and was associated with reduced PPO activity (Fig. 4). Mesocarp discoloration was further reduced, when the 1MCP (100 $\mathrm{nl}^{-1}$ ) was applied a second time during cold storage, and the fruit still softened normally at shelf life (Fig. 4). On the other hand, application of continuous ethylene $\left(4 \mu \mathrm{l} 1^{-1}\right)$ caused $100 \%$ mesocarp discoloration and a significant increase in PPO activity (Fig. 4). All fruit, except the ethylene-treated ones, softened to the same extent after 5 days of shelf life. Only the continuously ethylene-treated fruits were much softer and were discarded after 3 days at $20{ }^{\circ} \mathrm{C}$.

In another experiment on 'Hass' fruit later in the season, 1-MCP application reduced mesocarp discoloration and decay development in fruit stored for 5 weeks at 5 or $3{ }^{\circ} \mathrm{C}$ (Fig. 5). The reduction in mesocarp discoloration was similar in fruits treated with $1-\mathrm{MCP}$ at 100 or $300 \mathrm{nl} 1^{-1}$ (Fig. 5(A)). Decay development was lower in control and 1-MCP-treated fruit stored at $5{ }^{\circ} \mathrm{C}$ than in those at $3{ }^{\circ} \mathrm{C}$ (Fig. 5(B)).

\section{Discussion}

CI symptoms, expressed as mesocarp discoloration, probably result from a combination of the presence of ethylene in the tissue and a low temperature environment. The higher mesocarp discoloration in Ethrel-treated fruit stored at 4 and $6{ }^{\circ} \mathrm{C}$ than in those at $8{ }^{\circ} \mathrm{C}$, and the healthy appearance of those stored at $20{ }^{\circ} \mathrm{C}$ (Fig. 1) showed clearly that the combination of ethylene with cold temperature caused damage to the avocado pulp. In untreated 'Ettinger' fruit, there was more mesocarp discoloration at the lower temperature $\left(4^{\circ} \mathrm{C}\right)$ than at 6 or $8{ }^{\circ} \mathrm{C}$, in accordance with earlier research showing a higher sensitivity of this cultivar to $\mathrm{CI}$ at $4{ }^{\circ} \mathrm{C}$ compared to $6{ }^{\circ} \mathrm{C}$ (Zauberman et al., 1973)

Acceleration of softening by ethylene applied prior to cold storage was negligible (Table 1), in agreement with the findings of Zauberman and Fuchs (1973), who showed that only continuously applied ethylene at low temperature caused acceleration of softening and ripening, while application for $24 \mathrm{~h}$ was not enough. In the present experiment, application of ethylene $\left(100 \mu 11^{-1}, 24\right.$ $\mathrm{h}$ at $20{ }^{\circ} \mathrm{C}$ ) prior to cold storage caused severe CI symptoms to the skin of 'Fuerte' fruit, exhibited as pitting and darkening of the peel, in addition to mesocarp discoloration, which intensified during shelf life. Moreover, the CI symptoms were associated with impaired softening during shelf life at $20{ }^{\circ} \mathrm{C}$ (Table 1). It was shown previously that one of the CI symptoms in 'Fuerte' and 'Hass' fruit is failure of the fruit to soften properly after removal from chilling temperatures (Eaks, 1976).

More mesocarp discoloration and stem-end rot development was found in 'Fuerte' fruit during shelf life following cold storage with longer ethylene exposure (48 vs. $12 \mathrm{~h}$ ) prior to cold storage (Fig. 2). The results of the various durations of 
ethylene application clearly demonstrated that ethylene exposure prior to cold storage could cause increased damage. This agrees with previous findings of induction of stem-end rot caused by Diplodia natalensis in ethylene-treated citrus fruit (Brown and Lee, 1993) and induction of fungal invasion by Colletotrichum gloeosporioides by ethylene (Flaishman and Kolattukudy, 1994). The main stem-end rot fungus in avocado is $C$. gloeosporioides, which causes great damage to the avocado industry in Israel (Prusky, 1996).

There was no change in softening following a 12-h ethylene application, and only a very slight change in fruit softening after 24-48 h. This agrees with the findings of Zauberman et al. (1988), who showed that a $12 \mathrm{~h}$ ethylene application did not trigger softening. The appearance of CI is not related to softening, and it has been found in a more severe form in firm preclimacteric fruit (Paull, 1990).

There was more mesocarp discoloration and stem-end rot development after 3 weeks of cold storage, in 'Fuerte' fruit treated with ethylene, stored at $3{ }^{\circ} \mathrm{C}$ than in that stored at $5{ }^{\circ} \mathrm{C}$ (Fig. 2). This was probably because at the lower temperature there was more membrane damage, which is the primary response of plants to chilling stress (Wang, 1982).

Use of MA enabled us to study the effects of reduced ethylene concentrations in the atmosphere around the fruit, on mesocarp discoloration and decay development. Ethylene reduction was achieved by direct absorption of ethylene and perhaps by elimination of autocatalytic formation of new ethylene. Slowing the ripening process, by lowering the ethylene concentration in the atmosphere around fruit, led to reduced $\mathrm{CO}_{2}$ and higher $\mathrm{O}_{2}$ concentrations (Fig. $3)$. Avocados stored in MA with low ethylene exhibited lower levels of mesocarp discoloration and stem-end rot development. This demonstrated the role of ethylene in intensifying mesocarp discoloration and stem-end rot development following 5 weeks of storage at $5{ }^{\circ} \mathrm{C}$. Our results are in agreement with others that show reduction in $\mathrm{CI}$ in avocado expressed as mesocarp discoloration, through removal of ethylene by an absorbent (Hatton and Reeder,
1972). The greater stem-end rot development under MA conditions with high ethylene concentrations $\left(3 \mu \mathrm{l}^{-1}\right)$ corresponds to the in vitro induction of $C$. gloeosporioides by ethylene (Flaishman and Kolattukudy, 1994).

Recently, it has been shown that application of 1-MCP to avocado fruit at a very low concentration of $30-70 \mathrm{nl} 1^{-1}$ for $24 \mathrm{~h}$ was capable of extending shelf life at $20{ }^{\circ} \mathrm{C}$ by delaying ethylene production (Feng et al., 2000). A similar low concentration $\left(100 \mathrm{nl}^{-1}\right)$ was also effective in delaying banana ripening (Jiang et al., 1999). In the present study, with application at $5{ }^{\circ} \mathrm{C}$, and not $20{ }^{\circ} \mathrm{C}$, a longer application or a second application of $100 \mathrm{nl}^{-1}$ for 24 or $48 \mathrm{~h}$ was more effective in improving avocado quality than only one application of $100 \mathrm{nl}^{-1}$ for $24 \mathrm{~h}$ (Fig. 4). In banana, Jiang et al. (1999) found that application of $500 \mathrm{nl} 1^{-1}$ of ethylene in PE bags was more effective than $100 \mathrm{nl} \mathrm{l}^{-1}$, while application of $1000 \mathrm{nl}^{-1}$ was not more effective, but did not cause damage. However, when 1-MCP was applied twice at $300 \mathrm{nl} \mathrm{1}^{-1}$ for $24 \mathrm{~h}$ during cold storage, avocado fruit failed to ripen during shelf life, which indicated that 1$\mathrm{MCP}$, in higher concentrations, can be effective also at $5{ }^{\circ} \mathrm{C}$ (Table 3). Application of AVG (an inhibitor of ethylene synthesis) plus NBD (an inhibitor of ethylene action) to avocado slices completely inhibited ethylene production and expression of cellulase and polygalacuronase (PG) genes (Starrett and Laties, 1993). It is possible that applying excess 1-MCP can lead to irreversible inhibition of softening, because both the cellulase and PG enzymes are regulated by ethylene and are initiated by the climacteric rise (Starrett and Laties, 1993).

One aim of the present study was to evaluate the efficacy of 1-MCP in preventing $\mathrm{CI}$ in stored avocado. It is obvious that $1-\mathrm{MCP}$ reduced the harmful effect of ethylene in cold storage on mesocarp discoloration. Mesocarp discoloration was the lowest in 'Fuerte' fruit treated twice with 1-MCP $\left(100 \mathrm{nl} \mathrm{1}^{-1}\right)$ for $48 \mathrm{~h}$ during 4 weeks at $5{ }^{\circ} \mathrm{C}$, and this corresponded with the lowest PPO activity (Fig. 4). On the other hand, continuous application of ethylene $\left(4 \mu 1^{-1}\right.$ at $5{ }^{\circ} \mathrm{C}$ ) caused $100 \%$ pulp browning and the 
highest PPO activity. 'Fuerte' fruit easily develops mesocarp discoloration when exposed to oxygen, because the mesocarp contains high levels of phenols, as well as high PPO activity (Kahn, 1977; van Lelyveld and Bower, 1984). In previous work, we showed that low $\mathrm{O}_{2}$ atmospheres or application of acetaldehyde at $17{ }^{\circ} \mathrm{C}$ reduced CI symptoms in 'Fuerte' fruit and reduced browning of fruit mesocarp (Pesis et al., 1994, 1998). However, in the present work the application of 1-MCP was at $5{ }^{\circ} \mathrm{C}$ and during the treatment the $\mathrm{O}_{2}$ concentration was around $13 \%$, which did not induce acetaldehyde by anaerobiosis. Thus, the effect of 1-MCP cannot be attributed to the atmosphere during the treatment. The relatively low percentage of mesocarp discoloration $(7-12 \%)$ in the untreated 'Hass' fruit (Table 3, Fig. 5) was probably due to the fact that the fruit were placed into cold storage on the day of picking. At the first day of treatment, the production of ethylene was very low $\left(0.11 \mu \mathrm{l}^{-1} 24 \mathrm{~h}^{-1}\right)$, leading to low CI symptoms (Table 3 ). Our results are in agreement with those showing that CI incidence in 'Fuerte' fruit are more severe than in 'Hass' fruit, and in both cultivars it increased with prolonging the period between picking and cold storage (KremerKohne, 1999).

Application of ethylene prior to cold storage increased CI symptoms and decay development in fruit (Fig. 2), as has been shown in ethylenetreated citrus (Brown and Lee, 1993; Porat et al., 1999). However, in citrus, application of 1-MCP prevented fruit color development but increased decay development (Porat et al., 1999), whereas in avocado fruit we found a positive effect of 1-MCP in reduction of fungal development, although this was more in fruit stored at $3{ }^{\circ} \mathrm{C}$ and less at $5{ }^{\circ} \mathrm{C}$ (Fig. 5). The reduction in decay development could be an indirect result of the reduction in CI symptoms in these 1-MCP-treated fruit.

It is possible that ethylene induces PPO activity, whereas 1-MCP inhibits it. Recently, it was shown that the expression of three out of 11 clones, in addition to ACC oxidase cDNA, were reduced by 1-MCP treatment used in ripening Japanese pear (Itai et al., 2000).

\section{Acknowledgements}

Contribution from Chief Scientist of the Ministry of Agriculture, Israel. Project no. 402-064-00 and from the Agricultural Research Organization, The Volcani Center, Bet Dagan, Israel, no. 427/ 00 .

\section{References}

Bower, J.P., Cutting, J.G.M., Truter, A.B., 1989. Modified atmosphere storage and transport of avocados - what does it mean? South Africa Avocado Growers Assoc. Yrb. 12, 17-20.

Bradford, M.M., 1976. A rapid and sensitive method for quantitation of microgram quantities of protein utilizing the principle of protein-dye binding. Anal. Biochem. 72, $248-254$.

Brown, G.E., Lee, H.S., 1993. Interactions of ethylene with citrus stem-end rot caused by Diplodia natalensis. Phytopathology 83, 1204-1208.

Chaplin, G.R., Wills, R.B.H., Graham, D., 1982. Objective measurement of chilling injury in the mesocarp of stored avocado. HortScience 17, 238-239.

Cutting, J.G.M., Bower, J.P., Wolstenholme, B.N., Hofman, P.J., 1990. Changes in ABA, phenolic compounds and polyamines and their relationship with mesocarp discoloration in ripening avocado (Persea americana Mill.) fruit. J. Hort. Sci. 65, 465-471.

DeWilde, R.C., 1971. Practical applications of (2-chloroethyl) phosphonic acid in agricultural production. HortScience 6 , $364-370$.

Eaks, I.L., 1976. Ripening, chilling injury, and respiratory response of 'Hass' and 'Fuerte' avocado fruit at $20{ }^{\circ} \mathrm{C}$ following chilling. J. Amer. Soc. Hort. Sci. 101, 538-540.

Feng, X., Apelbaum, A., Sisler, E.C., Goren, R., 2000. Control of ethylene responses in avocado fruit with 1-methylcyclopropene. Postharvest Biol. Technol. 20, 143-150.

Flaishman, M.A., Kolattukudy, P.E., 1994. Timing of fungal invasion using host's ripening hormone as a signal. Plant Biol. 91, 6579-6583.

Hatton, T.T., Reeder, W.F., 1972. Quality of 'Lula' avocados stored in controlled atmospheres with or without ethylene. J. Amer. Soc. Hort. Sci. 97, 339-341.

Itai, A., Tanabe, K., Tamura, F., Tanaka, T., 2000. Isolation of cDNA clones corresponding to genes expressed during fruit ripening in Japanese pear: involvement of the ethylene signal transduction pathway in their expression. J. Exp. Bot. 51, 1163-1166.

Jiang, Y., Joyce, D.C., Macnish, A.J., 1999. Extension of the shelf life of banana fruit by 1-methylcyclopropene in combination with polyethylene bags. Postharvest Biol. Technol. 16, 187-193.

Kahn, V., 1976. Polyphenol oxidase isoenzymes in avocado. Phytochemistry 15, 267-272. 
Kahn, V., 1977. Some biochemical properties of polyphenol oxidase from two avocado varieties differing in their browning rates. J. Food Sci. 42, 38-43.

Kremer-Kohne, S., 1999. Hot water treatment of avocado fruit to induce cold tolerance. South Africa Avocado Growers Assoc. Yrb. 22, 48-51.

Meir, S., Naiman, D., Akerman, M., Hyman, J.Y., Zauberman, G., Fuchs, Y., 1997. Prolonged storage of 'Hass' avocado fruit using modified atmosphere packaging. Postharvest Biol. Technol. 12, 51-60.

Paull, R.E., 1990. Chilling injury of crops of tropical and subtropical origin. In: Wang, C.Y. (Ed.), Chilling Injury of Horticultural Crops. CRC Press, Boca Raton, FL, pp. 17-36.

Pesis, E., Marinansky, R., Zauberman, R., Fuchs, Y., 1994. Prestorage low oxygen atmosphere treatment reduces chilling injury symptoms in 'Fuerte' avocado fruit. HortScience 29, 1042-1046.

Pesis, E., Faiman, D., Dori, S., 1998. Postharvest effects of acetaldehyde vapour on ripening-related enzyme activity in avocado fruit. Postharvest Biol. Technol. 13, 245-253.

Porat, R., Weiss, B., Cohen, L., Daus, A., Goren, R., Droby, S., 1999. Effects of ethylene and 1-methylcyclopropene on the postharvest qualities of 'Shamouti' oranges. Postharvest Biol. Technol. 15, 155-163.

Prusky, D., 1996. Pathogen quiescence in postharvest disease. Ann. Rev. Phytopathol. 34, 413-434.

SAS, 1998. SAS/STAT User's Guide, Release 6.03 ed., SAS Institute, Cary, NC.
Scott, K.J., Chaplin, G.R., 1978. Reduction of chilling injury in avocados stored in sealed polyethylene bags. Trop. Agric. (Trinidad) 55, 87-90.

Sisler, E.C., Serek, M., 1997. Inhibitors of ethylene responses in plants at the receptor level: recent developments. Physiol. Plant 100, 577-582.

Starrett, D.A., Laties, G.G., 1993. Ethylene and wound-induced gene expression in the preclimacteric phase of ripening avocado fruit and mesocarp discs. Plant Physiol. 103, 227-234.

van Lelyveld, L.J., Bower, P., 1984. Enzyme reactions leading to avocado fruit mesocarp discoloration. J. Hort. Sci. 59, 257-263.

Wang, C.Y., 1982. Physiological and biochemical responses of plants to chilling stress. HortScience 17, 173-186.

Woolf, A.B., Watkins, C.B., Bowen, J.H., Lay-Yee, M., Maindonald, J.H., Ferguson, I.B., 1995. Reducing external chilling injury in stored 'Hass' avocados with dry heat treatments. J. Amer. Soc. Hort. Sci. 120, 1050-1056.

Zauberman, G., Fuchs, Y., 1973. Ripening processes in avocados stored in ethylene atmosphere in cold storage. J. Amer. Soc. Hort. Sci. 98, 477-480.

Zauberman, G., Schiffmann-Nadel, M., Yanko, U., 1973. Susceptibility to chilling injury of three avocado cultivars at various stages of ripening. HortScience 86, 511-513.

Zauberman, G., Fuchs, Y., Yanko, U., Akerman, M., 1988. Response of mature avocado fruit to postharvest ethylene treatment applied immediately after harvest. HortScience 23, 588-589. 